\author{
Katarzyna NizioŁeK \\ INSTYTUT SOCJOLOGII \\ UNIWERSYTET W BIAŁYMSTOKU \\ E-MAIL: KATARZYNA.NIZIOLEK@GMAIL.COM
}

„Sztuka jest po stronie uciśnionych. Pomyśl zanim wzdrygniesz się na upraszczające dictum

i jego heretycką definicję wolności sztuki.

Bo jeśli sztuka oznacza wolność ducha,

jak może istnieć wśród uciskających?"

[E. Wharton, za: Clover, Stalker 2007: 3, tłum. KN].

\title{
SZTUKA JAKO NARZĘDZIE SPOŁECZNEJ INKLUZJI. PERSPEKTYWA SOCJOLOGICZNA ${ }^{1}$
}

\section{Perspektywa socjologiczna}

W świetle klasycznej teorii socjologicznej procesy ekskluzji i inkluzji społecznej wiążą się ze zjawiskiem zamykania się (ang. closure) klas społecznych i grup statusowych. Koncepcję tę wprowadził do socjologii Max Weber, jeden z prekursorów tej nauki, a w późniejszym okresie rozwijali ją m.in. Anthony Giddens, Frank Parkin i Raymond Murphy. Według Webera zamykanie się jest środkiem ograniczenia ruchliwości społecznej i reprodukcji szans życiowych. Dlatego stanowi podstawę nierówności społecznych o różnym charakterze: materialnym, prestiżowym i politycznym, ale także rasowym, etnicznym, kulturowym, płciowym (gender) czy geograficznym. Weber twierdził, że dowolna grupowa charakterystyka może być potencjalnie podstawą wykluczenia, jak również samowykluczenia (charakterystycznego np. dla współczesnych autorowi społeczności żydowskich) [Weber 1978: 43-46; także: Marshall 1998: 79; Domański 2004: 166-169].

Ujmując rzecz ogólnie, o zamykaniu się mówimy wtedy, gdy jedna zbiorowość odmawia innej dostępu do nagród materialnych i społecznych (afiliacji,

\footnotetext{
1 Artykuł przygotowano w ramach projektu badawczego „Sztuka społeczna w Polsce. Badanie jakościowe", realizowanego w latach 2010-2012 w związku z pracą doktorską Sztuka społeczna. Obywatelski wymiar działań społeczno-artystycznych i sfinansowanego ze środków Narodowego Centrum Nauki. Wykorzystano w nim fragmenty rozprawy doktorskiej.
} 
uznania, prestiżu) opierając się na kryteriach (fizycznych lub społecznych), które jednocześnie stara się ideologicznie usprawiedliwić (uprawomocnić). Mechanizm ten kształtuje i podtrzymuje m.in. relację dominacji - podporządkowania, większości - mniejszości. Rewersem tego zjawiska, określanego także jako monopolizacja przywilejów, jest uzurpacja dostępu do tychże przywilejów przez grupę podporządkowaną (wykluczaną, marginalizowaną). Uzurpacja nie jest działaniem indywidualnym, lecz zbiorowym; przybiera postać protestów, ruchów społecznych, a w skrajnym przypadku - rewolucji. Jest zatem siłą demokratyzującą [por. Parkin 1979].

W ujęciu tym uwagę zwraca dynamiczny, a nie statyczny charakter struktury społecznej - wyłaniającej się z ciągłego napięcia pomiędzy przeciwstawnymi procesami ekskluzji i inkluzji, gdzie pierwsza oznacza zdolność (władzę) narzucania społecznych podziałów i hierarchii, a druga ich przekraczania, uwalniania się od obowiązującej logiki wykluczenia, emancypacji. Strategie zamykania dostępu do zasobów i szans życiowych opierają się na rywalizacji aktorów (agentów) społecznych i ich wzajemnie dyskryminujących praktykach, a nie są wyrazem utrwalonej struktury społecznych pozycji. Są społecznymi działaniami, poprzez które struktura społeczna się reprodukuje (odtwarza, zachowuje ciągłość) i przez które może być zmieniana.

W ujęciu socjologicznym ekskluzja i inkluzja społeczna są zatem podstawowymi mechanizmami strukturyzacji społeczeństwa, zarówno w wymiarze pionowym (stratyfikacji, uwarstwienia), jak i poziomym (relacji, podziałów i dystansów międzygrupowych, w tym międzykulturowych). Odnoszą się do procesów zamykania (się) i otwierania (się) struktur społecznych: grup statusowych, zawodowych, etnicznych i innych, stopnia przenikalności ich granic. Choć inkluzja jest procesem o kierunku przeciwnym do ekskluzji, nie polega na jej prostym odwróceniu - wkluczaniu wykluczonych czy też ich odzyskiwaniu dla społeczeństwa (resocjalizacji). Kwintesencją inkluzji jest społeczna transformacja polegająca na zmianie w obszarze reguł i praktyk społecznej ekskluzji i/lub uzasadniających je wyobrażeń2 ${ }^{2}$

W terminologii socjologicznej istnieją co najmniej trzy sposoby rozumienia społecznego wykluczenia. Pierwsze dotyczy praw i ich ograniczeń. Wiąże więc procesy ekskluzji z funkcjonowaniem społeczeństwa obywatelskiego. Drugie odnosi się do społecznej izolacji, kategorii anomii (rozchwiania normatywnego) i problemów społecznej integracji (kryzysu społecznej solidarności). Trze-

\footnotetext{
2 Transformacja może polegać np. na zastąpieniu kolektywnych kryteriów ekskluzji kryteriami indywidualnymi. Podstawą wykluczenia przestaje być wówczas przynależność do danej grupy czy kategorii społecznej (np. rasowej, etnicznej, płci), a stają się cechy jednostkowe, takie jak: wiedza, umiejętności, doświadczenie, zasługi, zdolności.
} 
cie oznacza skrajną marginalizację, szczególnie w kontekście społeczeństwa wielokulturowego [Marshall 1998: 2013]. Marshall Wolfe wyróżnia aż sześć dystynktywnych wymiarów wykluczenia społecznego:

1. $\mathrm{z}$ dostatecznego poziomu bytowania (np. z powodu utraty pracy, zdrowia, sprawności);

2. ze świadczeń socjalnych (z powodu wycofywania się państwa $z$ funkcji opiekuńczych);

3. z kultury konsumenckiej (z powodu względnego ubóstwa);

4. $\mathrm{z}$ politycznego wyboru (z powodu niedorozwoju struktur obywatelskich i kultury uczestnictwa);

5. z sieci organizacji obywatelskich i ze społecznej solidarności (z powodu dezintegracji społecznej, atrofii wspólnotowych więzi społecznych);

6. z rozumienia tego, co się dzieje (z powodu szybkiego tempa rozwoju technologicznego i przyrostu informacji) [Wnuk-Lipiński 2005: 273-274].

Nie można też zapominać, że różne rodzaje wykluczenia kumulują się.

Wykluczenie społeczne jest więc pojęciem szerokim, uwzględniającym różne obszary partycypacji, solidarności (więzi) i dostępu, odnoszącym się tak do sfery materialno-bytowej, jak społecznej, kulturowej i politycznej. W tym kontekście inkluzja społeczna łączy się z powszechnym, zbiorowym (kolektywnym) uczestnictwem, a jej miarą jest aktywność obywatela jako członka wspólnoty. Nie dotyczy podklasy, ale wszystkich członków i członkiń społeczeństwa. Ostatecznym środkiem inkluzji społecznej jest więc demokracja, rozumiana nie w kategoriach systemu politycznego, ale sposobu organizacji życia społecznego we wszystkich jego wymiarach, którego podstawę stanowi równość możliwości (szans życiowych) ${ }^{3}$.

Działanie demokracji [...] polega zarazem na zmniejszaniu odległości między różnymi pozycjami w ramach społecznej struktury i na redukcji samej ich trwałości. Najprościej mówiąc, demokracja sprzyja egalitaryzacji i społecznej ruchliwości. Można wręcz powiedzieć, że nie jest niczym innym niż związkiem tych dwóch procesów. W tym sensie stanowi dekonstrukcję stabilnej struktury społecznej, zakładającej określoną hierarchię lub określony system dystrybucji podstawowych dóbr. Jest tym, co kwestionuje i rozsadza każdy taki system, tym, co wymusza jego ciągła restrukturyzację [Kowalska 2010: 105].

Patrząc na kwestię społecznej inkluzji z tej dynamicznej, wieloaspektowej i prodemokratycznej perspektywy dostrzegamy możliwość wpływania na spo-

3 Szanse życiowe, także szanse rynkowe albo szanse ruchliwości - pojęcie odnoszące się do możliwości osiągnięcia przez jednostkę pożądanych przez nią wartości, w szczególności awansu społecznego, co jest zależne od jej ulokowania w strukturze społecznej. 
łeczną strukturę zarówno na poziomie praktyk ekonomicznych i politycznych, jak też kulturowych. Należą do niech także rozmaite oddolne działania podejmowane w obszarze edukacji, kultury i sztuki, kształtujące zręby demokracji kulturowej. Działania te nie mogą być traktowane jako zastępcze względem zorientowanej na społeczną inkluzję redystrybucyjnej polityki państwa (znacznie obecnie ograniczonej $)^{4}$, ale ich dostrzeżenie i docenienie może istotnie poszerzyć repertuar środków konstruowania inkluzywnego, otwartego, demokratycznego, wielokulturowego społeczeństwa.

\section{Sztuka jako narzędzie inkluzji społecznej}

Jak piszą Darlene E. Clover i Joyce Stalker [2007: 8, cyt. tłum. KN], demokracja kulturowa „kwitnie tylko w tych społeczeństwach, które stymulują szerokie uczestnictwo w sztuce i w których dzieła sztuki ocenia się nie tylko pod kątem ich walorów estetycznych, lecz także ich funkcji terapeutycznych i społecznych". Jako idea filozoficzna i polityczna demokracja kulturowa wyrasta ze sprzeciwu wobec kulturowego wykluczenia, czyli instytucjonalnego wyłączenia większości ludzi (sic!) z procesów tworzenia sztuki. Opiera się na przekonaniu o ekskluzywności istniejących instytucji artystycznych, które nie uwzględniają zróżnicowanych potrzeb i aspiracji kulturowych różnych grup etnicznych i społecznych oraz o możliwości zmiany sposobu ich funkcjonowania na bardziej inkluzywny poprzez rozszerzenie partycypacji, czyli zaangażowanie ludzi z reguły nieuczestniczących w sztuce. Nie chodzi przy tym po prostu o poszerzanie widowni poprzez zwiększanie dostępu zróżnicowanej publiczności do oferty instytucji sztuki (muzeów, galerii, teatrów) czy umieszczanie sztuki w przestrzeni publicznej, ale o szeroki i zróżnicowany oddolny udział obywateli w definiowaniu i tworzeniu sztuki. Sztuka zewnętrzna (outdoor art), która nie wchodzi w interakcje z otoczeniem społecznym, nie włącza się do sfery publicznej dyskusji, nie jest przejawem demokracji kulturowej, a co naj-

\footnotetext{
4 Poważnym zagrożeniem jest instrumentalizacja tego rodzaju „miękkich” praktyk, charakterystyczna dla europejskiej polityki kulturalnej, przy jednoczesnym wycofywaniu się państwa ze sfery „twardych” usług socjalnych. Na przykład w Wielkiej Brytanii rozwojowi w dziedzinie partycypacji w sztuce (community art, participatory art) towarzyszy zawężanie repertuaru innych, instytucjonalnych środków służących społecznej inkluzji (polityka zatrudnienia, opieka społeczna, ochrona zdrowia, edukacja), [por. Bishop 2012b]. Omówiony w dalszej części tekstu projekt „Universal” stanowi rodzimy przykład takiej substytucji. Projekt został wyłoniony w otwartym konkursie na artystyczną rewitalizację osiedla przy ulicy Dudziarskiej, ogłoszonym przez Urząd Miasta Stołecznego Warszawy i sfinansowany ze środków publicznych.
} 
wyżej jej fasadowej wersji. Dopiero wtedy, gdy w istotny sposób odnosi się do sytuacji jakiejś społeczności, jej kultury i angażuje tę społeczność w obrębie jej własnego kulturowego doświadczenia, jednocześnie rozszerzając granice tego doświadczenia (przełamując jego zamknięcie), zasługuje na miano publicznej [por. Lippard 1984] ${ }^{5}$. Demokratyczna kultura jest otwarta, traktuje wkład każdej grupy jako wartościowy, każdemu daje szansę na uczestnictwo. Jest wielogłosem różnych kultur i społeczności, które znajdują w niej swoją reprezentację [por. Webster 1997: 21]. Dla Rachel Davis DuBois demokracja kulturowa jest synonimem wielokulturowości, wiąże się z twórczym wykorzystaniem kulturowych różnic w społeczeństwie (a creative use of differences), [za: Graves 2005: $10-11]$.

Pytanie o efektywność sztuki jako narzędzia społecznej inkluzji jest więc pytaniem nie tylko o to, czy sztukę mogą tworzyć wykluczeni (z różnych porządków rzeczywistości społecznej, w tym z pola sztuki), ale także o to, czy i jaka sztuka pomaga zmieniać obowiązujące reguły społecznej ekskluzji, poszerzać możliwości demokratycznego uczestnictwa, stymulować kreatywne i refleksyjne (podmiotowe) działania jednostek. Funkcje, jakie w tym kontekście mogą wypełniać działania artystyczne to w szczególności: poszerzanie sfery publicznej, kreowanie społecznego dyskursu i wyobrażeń, wyrażanie konfliktów społecznych, konstruowanie sytuacji otwartej komunikacji (dialogu), facylitacja procesu poznawania Innego/Obcego, symboliczna i/lub fizyczna reorganizacja przestrzeni publicznej, a także społeczna terapia. Krótko mówiąc, inkluzja społeczna poprzez sztukę wymaga przekształcania zastanych struktur społecznych od wewnątrz, czy inaczej - ich dynamizowania. Czy jest to zadanie, któremu sztuka może sprostać?

Wydaje się, że rosnąca, choć wciąż nieliczna, grupa współczesnych artystów wychodzi poza przypisaną im rolę krytyków społecznych (kontestujących status quo i unaoczniających relacje władzy) i jest żywo zainteresowana możliwościami społecznej interwencji i współdziałania $\mathrm{z}$ różnymi społecznościami. Do grupy tej możemy m.in. zaliczyć: Johna Ahearna (rzeźby na Bronksie), Pawła Althamera (Klasa Einsteina, Pan Guma, Bródno 2000, Raj, Wspólna sprawa, współpraca z grupą arteterapeutyczną Nowolipie), Suzanne Lacy (Crystal Quilt, Code 33), Johna Malpede’a (Los Angeles Poverty Department), Oiko Petersena (Guys. From Poland with Love, Downtown Collection), nieżyjącego już Christopha Schlingensiefa (Passion Impossible, CHANCE 2000), Krzysztofa

\footnotetext{
5 Dla odróżnienia sztuki publicznej od sztuki zewnętrznej, często nazywanej publiczną, stosuje się niekiedy termin „nowa sztuka publiczna” (new genre public art), [zob. Lacy 1995]. Istnieje także rozróżnienie na sztukę w przestrzeni publicznej i sztukę w interesie publicznym [zob. Raven 1989; Kwon 2004]. Więcej na temat współczesnej sztuki publicznej w Polsce [Niziołek 2012].
} 
Wodiczkę (Laska tułacza, Rzecznik, Pojazdy bezdomnych, publiczne projekcje). Już tylko wymienieni twórcy stosują bardzo różne media i metody pracy: od rzeźby, poprzez fotografię, instalację, projekcję wideo, po performans i teatr. Różnie rozkładają akcenty między twórcą, wykonawcą i odbiorcą. W różny sposób podchodzą do problemów: autorstwa, podmiotowości uczestnika, wspólnotowości („naturalnej” i politycznej). W różnych proporcjach mieszają to, co artystyczne z tym, co społeczne. W różny sposób definiują swoją własną rolę, nie tyle zawodową, co społeczną.

Sztuka zorientowana na zmianę społeczną niełatwo poddaje się analizie estetycznej, ponieważ równie ważne (jeśli nie ważniejsze) są dla niej cele społeczne i sposób ich osiągania, proces dochodzenia do nich: poprzez partycypację nie-artystów, działanie w sferze publicznej, zbliżanie sztuki i codziennego doświadczenia ${ }^{6}$. Proponuję określać tego typu działania jako sztukę społeczną, którą możemy zdefiniować jako kombinację pięciu wzajemnie powiązanych elementów:

1) celu działania - wyrażonego w kategoriach pożytku publicznego lub zmiany społecznej (np. edukacja obywatelska, aktywizacja społeczna, inkluzja społeczna);

2) uczestników działania - określonych w sposób ogólny, w kategoriach grupowych lub zbiorowych (np. społeczność lokalna, imigranci, kobiety);

3) sposobu angażowania uczestników w działanie - jako twórców lub odbiorców sztuki - bez względu na ich formalne przygotowanie do działalności tego rodzaju, minimalizującego bariery uczestnictwa i odbioru;

4) społecznej przestrzeni działania - jego lokalizacji w sferze publicznej, pozainstytucjonalnej, na poziomie struktur społecznych średniego szczebla, na zewnątrz zarówno świata sztuki, jak i publicznych instytucji kultury (takich jak: muzea, galerie, teatry);

5) jakości działania - jego obywatelskiego charakteru, przejawiającego się nie tylko w oddolności (prywatnej inicjatywie), samoorganizacji, spontaniczności i responsywności, ale też przywiązaniu do obywatelskich wartości ${ }^{7}$.

6 Dlatego także w obszarze teorii i krytyki artystycznej pojawiają się alternatywne wobec dotychczasowych ujęć estetyczno-historycznych koncepcje sztuki, takie jak: estetyka relacyjna [Bouriaud 2010], sztuka konwersacyjna albo dialogiczna [Kester 2004] czy, wspomniana już, nowa sztuka publiczna [Lacy 1995].

7 Więcej na temat koncepcji sztuki społecznej [Niziołek 2008, 2009a, 2009b]. 
Sztuka galeryjna, wysoka, burżuazyjna (mieszczańska), komercyjna, a nawet awangardowa (jeśli ograniczymy znaczenie awangardy do rozwiązań formalnych) nie ma mocy zmieniania społeczeństwa, a raczej zmiany zachodzące w społeczeństwie odzwierciedla. Potrzeba społecznego sprawstwa kieruje więc aktywność artystów w stronę przestrzeni publicznej, społeczności lokalnych i grup mniejszościowych, które stanowią najbardziej charakterystyczne konteksty sztuki społecznej. Jest to, o czym przekonuje Maria Anna Potocka [2008: 251], „eksperyment zainicjowany przez samą sztukę”. To nie wykluczeni ze świata sztuki (czyli większa część społeczeństwa) szturmują jego bramy i mury, uzurpując dostęp do jego dobrodziejstw, lecz transgresyjnie zorientowani artyści poszukują obopólnie znaczącego kontaktu z publicznością. Piotr Piotrowski [2010: 7] nazywa to zjawisko „agorafilią”. Określenie to jest o tyle przydatne dla proponowanego podejścia do zagadnienia społecznej inkluzji, o ile odsyła wprost do pojęcia starożytnej agory - przestrzeni publicznej, rozumianej jako przestrzeń bezpośredniego uczestnictwa wolnych i równych obywateli oraz kształtowania przez nich ładu społecznego (notabene także za pomocą strategii ekskluzywnych, takich jak ostracyzm).

Jako praktyka artystyczna wychodząca poza pole sztuki i jednocześnie enklawa aktywności o charakterze obywatelskim, sztuka społeczna nie tylko włącza w działanie twórcze nie-artystów, ale też może być przez nie-artystów inicjowana, animowana, praktykowana. Jest więc ściśle związana z procesem demonopolizacji uprawnień twórczych i demokratyzacji sztuki - jej poszerzenia, rozumianego jako powszechna możliwość podejmowania samodzielnej aktywności artystycznej, beuysowskiego bycia artystą ${ }^{8}$. Przy czym, bycie artystą jest tu rozumiane w kategoriach obywatelskich: nie oznacza tylko możliwości indywidualnej ekspresji, ale też zdolność kolektywnego oddziaływania na otoczenie, powodowania w nim zmian społecznych, kulturowych, politycznych.

Przedstawione w dalszej części tekstu przykłady - muralowego projektu „Universal”, rzeźby Pana Gumy i spektaklu dokumentalnego Import/Export - pozwolą bliżej określić możliwości i ograniczenia sztuki jako narzędzia społecznej inkluzji i stworzyć katalog praktycznych wskazówek dla społecznych praktyków (w tym nauczycieli i edukatorów) zainteresowanych tą formą dzia-

8 Joseph Beuys (1922-1986), niemiecki artysta, teoretyk sztuki i działacz społeczno-polityczny, powszechnie uznawany za prekursora myślenia o każdym człowieku jako o artyście. Przewodnim celem jego pracy dydaktycznej, społecznej i artystycznej było uświadamianie ludziom, że mogą i muszą nauczyć się bycia twórczymi. Mawiał, że „każdy może być artystą”. Nie w sensie twórcy dzieł tradycyjnie pojmowanej sztuki, ale twórczego myślenia i świadomego kształtowania własnego otoczenia: politycznego, ekonomicznego i społeczno-kulturowego. Twórczość i sztukę postrzegał Beuys jako środek radykalnej transformacji społecznej. Uważał, że sztuka, która nie może kształtować społeczeństwa, w ogóle nie jest sztuką [Kaczmarek 2001, także: Niziołek 2011]. 
łania. Każde z tych przedsięwzięć posługuje się inną strategią uzurpacji, wpływania na reguły społecznej ekskluzji/inkluzji: od wytrącenia społeczności z symbolicznej równowagi, poprzez wyartykułowanie zbiorowej, lokalnej tożsamości, po spotkanie międzykulturowe (i międzyludzkie zarazem). Przykłady te celowo nie zostały dobrane według popularnego klucza tzw. dobrych praktyk, lecz pod kątem ich przydatności jako punktów odniesienia, zarówno pozytywnych, jak i negatywnych, dla bardziej krytycznej refleksji i praktyki społecznej.

\title{
Przykład 1: „Universal” a problem podwójnego wykluczenia9
}

Działanie artystyczne w przestrzeni pozagaleryjnej, otwartej, publicznej ma swoją własną specyfikę. Przede wszystkim wymaga uwzględnienia użytkowników tej przestrzeni, o czym wielu artystów zdaje się zapominać. Problem ten doskonale ujmuje rosyjski konceptualista Ilia Kabakow [2010: 346], według którego to widz, mieszkaniec ulicy czy miasta, a nie artysta, który tylko realizuje tam swój projekt, jest „panem miejsca”.

\begin{abstract}
Na każdą pojawiającą się nowość patrzy jak właściciel mieszkania, któremu ktoś chce coś wstawić, dlatego musi to zaakceptować, uznać za naturalny element swojego życia albo odrzucić, potraktować jako rzecz bezużyteczną, zbędną, niekonieczną - reakcja ta jest całkowicie naturalna i zrozumiała. Zmienia to jednak w zasadniczy sposób relację między projektem publicznym i widzem, ponieważ to widz mieszka w miejscu, gdzie artysta jest jedynie zaproszonym gościem.
\end{abstract}

W pułapkę odgórnego, arbitralnego i przemocowego (w sensie symbolicznym) działania wpadli Grzegorz Drozd i Alicja Łukasiak (związani z Fundacją Zmiana Organizacji Ruchu - ZOR), autorzy zrealizowanego w 2010 roku projektu „Universal”, którego kluczowym elementem były murale na osiedlu bloków socjalnych przy ulicy Dudziarskiej w Warszawie. Osiedle Dudziarska zostało stworzone w połowie lat dziewięćdziesiątych ubiegłego wieku na potrzeby zakwaterowania mieszkańców eksmitowanych z innych dzielnic Warszawy, w sąsiedztwie więzienia i spalarni śmieci, bez instalacji gazowej i grzewczej. Szybko zamieniło się w getto, osiedle biedy, do tego fizycznie i organizacyjnie odizolowane od reszty miasta - usytuowane za torami kolejowymi, z jednym połączeniem autobusowym. Projekt „Universal” opierał się na odtworzeniu

9 Na temat projektu „Universal”: [Niżyńska 2011; Debiliada... 2010; Drozd 2010; Rypson 2010; Sikora 2010; Watts 2010; Szabłowski 2011]. Zob. też: http://zorfoundation.org/zor/universal.html [07.08.2013]. 
w monumentalnej skali modernistycznych obrazów Kazimierza Malewicza (Czarny kwadrat) i Pieta Mondriana (jednej z Kompozycji) na ścianach trzech bloków należących do osiedla i w ten sposób zderzeniu społeczno-artystycznej utopii z rzeczywistością życia w inspirowanych nią realiach. Oprócz bezpośredniej ingerencji w przestrzeń osiedla, w ramach projektu powstał utrzymany w artystycznej konwencji film Etykieta zastępcza, ukazujący życie na Dudziarskiej (którego mieszkańcy w większości nie widzieli). Założonym pozaartystycznym celem projektu „Universal” było wzbudzenie refleksji i dyskusji na temat wykluczenia społecznego oraz zogniskowanie publicznej uwagi na problemach osiedla i żyjących tam ludzi ${ }^{10}$.

Modernistyczne murale spotkały się z odrzuceniem przez mieszkańców Dudziarskiej - nie tyle jednak ze względu na ich niezrozumiałość, co sposób, w jaki autorzy projektu potraktowali społeczność osiedla. Pomysł nie został z nimi w żaden sposób skonsultowany czy przedyskutowany. Nikt nie wyjaśnił mieszkańcom, dlaczego projekt ma być zrealizowany właśnie na ich osiedlu, dlaczego mają być to "malewicze i mondriany” (każdy z obrazów został zreplikowany na ścianach kolejnych bloków) i czemu całe działanie ma służyć. Autorzy projektu publicznie tłumaczyli tę sytuację niemożnością nawiązania komunikacji z mieszkańcami i bezpośrednim zagrożeniem, jakie odczuwali z ich strony. Zapytani, jaki mural chcieliby widzieć na swoim bloku, lokatorzy mieli odpowiedzieć: „pierdolnijcie jakieś kwiatki albo gołe baby” [Debiliada... 2010: 132]. Ze względu na presję ze strony mieszkańców pierwsza ekipa malarzy wykonujących murale zrezygnowała z pracy - według relacji Drozda, rzucano w nich wyzwiskami, przekleństwami i butelkami [Watts 2010]. Znamienne, że pomimo tak gwałtownej i jednoznacznej reakcji, projekt „na siłę”, wyraźnie wbrew woli mieszkańców, doprowadzono do końca.

Monumentalne murale i konflikt $\mathrm{z}$ lokalną społecznością, jaki spowodowały z pewnością przykuły do Dudziarskiej uwagę mediów, władz miasta i opinii publicznej. Przypomniano sobie o ludziach tam żyjących i ich trudnej sytuacji - jak pisze Patricia Watts [2010], praca Drozda „rzuciła światło na Dudziarską, gdzie dotąd panował mrok”. Postawiono jednocześnie ważne pytanie - o etyczny aspekt tego rodzaju ingerencji: Czy artysta, w ramach projektu finansowanego przez miasto, ma prawo wejść w przestrzeń publiczną bez pytania o zdanie jej użytkowników? Czy, używając metafory Kabakowa, może wstawić do cudzego mieszkania co mu się żywnie podoba? Czy może potraktować mieszkańców instrumentalnie, jako punkt odniesienia dla swoich działań? Watts [2010] pyta z kolei: „Czy dzieło sztuki realizowane w przestrzeni publicznej może oka-

10 http://zorfoundation.org/zor/universal.html [7.08.2013]. 
zać się „sukcesem”, jeśli artyście nie udało się porozumieć ze społecznością? Czy dialog taki jest konieczny? A jeśli nie, czy praca taka ma wartość bez względu na reakcję odbiorców?".

Jeśli wziąć w nawias moralną ocenę przedsięwzięcia, faktem pozostaje, że mieszkańcy Dudziarskiej nie mieli możliwości uczestnictwa w projekcie na żadnym jego etapie (ani planowania, ani wykonania). Takie uczestnictwo wymagałoby przygotowań, długiej obecności artysty w lokalnym środowisku, nie tylko pozyskania wiedzy na jego temat, ale też poznania go od środka, zaangażowania się, zbudowania relacji z lokalną społecznością, z różnymi, potencjalnie skonfliktowanymi jej segmentami ${ }^{11}$. Także gotowe murale nie wciągają przechodniów w interakcję, nie stawiają pytań, nie prowokują do refleksji czy dyskusji, jak robią to np. murale warszawskiego duetu Twożywo ${ }^{12}$ czy billboardy toruńskiej Galerii Rusz. Stanowią zamknięte dzieła, przeniesione z muzeum na ściany bloków, poznawczo niedostępne dla ludzi, którzy nie są przygotowani do recepcji nowoczesnej sztuki. Mówiąc o projekcie, Drozd wskazuje na potrzebę budzenia w ludziach (mieszkańcach Dudziarskiej) społecznej świadomości, a dokładniej świadomości ich społecznego położenia [Debiliada... 2010]. Nie da się jednak tak sformułowanego celu osiągnąć, posługując się językiem, którego ludzie ci nie znają, takim jak język modernizmu i jego pastiszu zaproponowanego przez artystę. Murale ZOR-u pozwalają „dotknąć rysy, która jest wpisana w samą zasadę nowoczesności" - pisze Stach Szabłowski [2011], objaśniając sens projektu. Ale to nie jest dyskurs Dudziarskiej. Dla jej mieszkańców modernistyczne obrazy na ich blokach są elementem nie tylko kulturowo obcym, ale też narzuconym, do tego przypominającym o ich wykluczeniu. To symbole braku władzy. W toku realizacji projektu, ludzie na co dzień pozbawieni możliwości pełnego uczestnictwa w życiu publicznym - zarówno w jego wymiarze politycznym, jak i kulturowym - zostali w sposób spektakularny i publiczny pozbawieni możliwości współdecydowania o swoim bezpośrednim otoczeniu. Projekt „Universal” przypieczętował wykluczenie mieszkańców Dudziarskiej nie dlatego, że wprowadził w obszar ich doświadczenia obce obrazy, ale dlatego,

11 Zwolenniczką takiego podejścia jest np. Suzanne Lacy, która uważa, że sztuka to nie tylko dzieło lub zdarzenie, lecz proces, na który składa się także: edukowanie społeczności, kształtowanie relacji z mass mediami, wybór przestrzeni działania, rekrutacja współpracowników i performerów, kontakty z organizacjami społecznymi i wiele innych z pozoru pozaartystycznych działań. Performanse Lacy są zawsze kulminacją wielomiesięcznej kolektywnej pracy w kontekście lokalnym, zaangażowania artystki i członków społeczności, wzajemnego poznawania się, wspólnych spotkań i działań. Kontekst, który Lacy określa jako „usytuowanie dzieła w obrębie życia społeczności lub społeczeństwa”, jest dla niej równie ważny, jak proces twórczy [Lacy 1989: 290, cyt. tłum. KN]. Pisownia oryginalna. 
że został zrealizowany w sposób wykluczający, bez ich udziału. Z tego powodu stanowi antyprzykład sztuki społecznej.

Artyści ZOR-u podjęli się działania w specyficznym i delikatnym środowisku społecznym, które na pewnym poziomie udało im się „poruszyć”, ale nie w kierunku, w jakim planowali. Uruchomili typową reakcję obronną, ograniczoną do własnego podwórka, określaną przez socjologów jako NIMBY - Not In My Back Yard. Artystyczna interwencja została zdefiniowana przez mieszkańców jako działanie wrogie, a nie potrzebne, pożyteczne czy choćby ciekawe. Stało się tak prawdopodobnie nie tylko dlatego, że nie przeprowadzili wcześniej starannego rozpoznania środowiska, w którym chcieli zrealizować swój projekt, ale także dlatego, że za metodę działania obrali „desant” - relatywnie szybką, jednorazową akcję, sterowaną z zewnątrz. Podczas gdy w takich warunkach, w pracy ze społecznością zaniedbaną i de facto pozbawioną praw, aby osiągnąć jakikolwiek pozytywny cel pozaartystyczny, konieczne jest długotrwałe zaangażowanie, zbudowanie wzajemnego zaufania i partnerskich relacji z mieszkańcami. Ich bezpośredni udział w projekcie legitymizowałby go i chronił przed dewastacją.

\begin{abstract}
Nawet społeczności niedoświadczające tego typu zaniedbań i zapraszające artystę do współpracy, np. do namalowania muralu, są oporne wobec zmian - podkreśla Watts. Gdy artysta proponuje dzieło sztuki wykraczające poza rozumienie danej społeczności lub nie trafia w ich własną estetykę, trudno jest mu uzyskać akceptację, nawet kiedy ma do czynienia z kulturą elitarną. Opór jest normalną reakcją w świecie sztuki publicznej, tym bardziej, że dzieła sztuki wpisują się wówczas w dany krajobraz najprawdopodobniej na stałe [Watts 2010].
\end{abstract}

\title{
Przykład 2: Pan Guma i granice partycypacji ${ }^{13}$
}

Pan Guma to rzeźba, która powstała w 2008 roku w efekcie współpracy artysty Pawła Althamera z kilkoma nastolatkami z warszawskiej starej Pragi, dzielnicy (podobnie jak Dudziarska) obciążonej wizerunkiem biednej, patologicznej i niebezpiecznej. Projekt zainicjowało stowarzyszenie Grupa Pedagogiki i Animacji Społecznej Praga Północ (GPAS), które zaprosiło Althamera, znanego m.in. ze współpracy z mieszkańcami Bródna (Bródno 2000, Raj, Wspólna spra$w a$, Mieszkania $X)$, do zrealizowania $\mathrm{z}$ ich podopiecznymi projektu artystycz-

13 Na temat rzeźby Pana Gumy m.in.: [Kowalska 2009; Lisicki 2009; Niech ludzie... 2009]. Zob. też: http://artmuseum.pl/pl/kolekcja/praca/althamer-pawel-guma [10.08.2013] oraz [Wokót kolekcji... 2009]. 
nego. Althamer i pedagodzy współpracowali już wcześniej przy projekcie Klasa Einsteina $^{14}$. Tym razem artysta zaproponował stworzenie pomnika dla dzielnicy, dla jej mieszkańców. Zadaniem uczestników było wytypowanie miejscowego bohatera, protagonisty, postaci, którą chcieliby w ten sposób uwiecznić. Wybór padł na Gumę, trzydziestokilkuletniego prażanina, garbatego alkoholika, stojącego zwykle pod jednym ze sklepów przy ulicy Stalowej. W efekcie powstały dwie naturalnych rozmiarów rzeźby: jedna została włączona do kolekcji Muzeum Sztuki Nowoczesnej, finansującego projekt, druga stanęła w miejscu, gdzie zwykle można było spotkać nieżyjącego już w tym momencie Gumę ${ }^{15}$. Rzeźba wykonana jest z tworzywa sztucznego, ubrana w zieloną kurtkę i umocowana do ziemi za pomocą sprężyny tak, że kiwa się na podobieństwo swego pierwowzoru.

Odsłonięcie pomnika, które miało miejsce w roku 2009, spotkało się z gwałtownym protestem mieszkańców, wyrażonym bezpośrednio podczas uroczystości, a później w ramach szerszej dyskusji w lokalnej prasie. Argumenty, których dostarczyli protestujący i dyskutanci można streścić następująco: rzeźba jest szkodliwa, bo wzmacnia negatywny stereotyp mieszkańca północnej Pragi; jest obraźliwa dla jej mieszkańców, którzy nie identyfikują się z tym stereotypem; promuje (głównie wśród młodzieży) negatywny wzór osobowy, zamiast go piętnować; dotyka poważnych społecznych problemów, ale w żaden sposób nie pomaga ich rozwiązać; sprzeniewierza publiczne środki, które powinny być wydawane na rozwiązywanie społecznych problemów, a nie ich manifestowanie. Argumenty te dobrze obrazują wypowiedzi internautów:

Znowu jakaś chora afirmacja menelstwa!!! Jak te biedne dzieci z Pragi mają wyjść poza swoje środowisko, gdy ciągle pokutuje jakiś niedorzeczny kult degenerata obecnie Pana Gumy? Kiwał się pod sklepem i pożyczał na fajki - genialny obiekt dla zblazowanego „artysty”, który śmiem podejrzewać, wychował się w innych realiach finansowych, ale w takiej samej pustce duchowej. Straszny syf [seba];

Strasznie głupi pomysł. Niestety. Fajnie, że dzieciaki miały zabawę, ale tym razem „uczestnicy” trafili kulą w płot. To przykre. Tutejsze dzieciaki potrzebują prawdziwych wzorów i bohaterów. Nie idoli w postaci menela... To żałosne, że powielane są stereotypy... „Będę menelem, postawią mi pomnik”. Gratuluję [x];

Projekt zrealizowany przez Althamera w 2005 roku w ramach niemieckiej komisji, mający celebrować stulecie śmierci Alberta Einsteina. Przez pół roku siedmiu młodych prażan (w większości relegowanych ze szkoły) uczyło się fizyki pod okiem nauczyciela, który sam stracił pracę w szkole $\mathrm{z}$ powodu niekonwencjonalnych metod nauczania. Zajęcia polegały na przeprowadzaniu eksperymentów naukowych w różnych nietypowych miejscach: w ogrodzie, w polu, na plaży, w studiu artysty, a następnie dzieleniu się zdobytą wiedzą, również za pomocą eksperymentów, z sąsiadami. Guma zmarł w trakcie realizacji projektu. 
Skandaliczna głupota!!! Jeżeli tak się pracuje z dzieciakami na Pradze, to gratuluję. Rozumiem, że wcześniej dzieci poznały życiorys pana Gumy (chyba nie wszystkie znały go osobiście), „bohater” zaimponował im do tego stopnia, że chciały go uwiecznić, płakać się chce. Chory pomysł, ale ktoś go zaakceptował, ktoś dał pieniądze... Wierzyć się nie chce, że można było zrealizować coś takiego, dając tym dzieciom taki wzór do naśladowania. Mam nadzieję, że szybko zniknie $[\mathrm{AB}]^{16}$.

Althamerowi nie można jednak zarzucić ani arbitralności wyboru protagonisty artystycznego przedstawienia, ani przemocowego wdzierania się w cudzą przestrzeń życiową. Gumę wybrali uczestniczący w projekcie chłopcy z Pragi, a przedstawiającą go rzeźbę umieścili „na swoim podwórku” - w miejscu, w którym, tak samo jak Gumie, przyszło im żyć. Andrzej Orłowski z GPAS-u podkreśla tkwiący w rzeźbie potencjał artykulacyjny. Przy pomocy Pana Gumy mieszkańcy Pragi mogą mówić o sobie i swoich problemach.

Chłopcy zdecydowali, że to ma być Guma, i to jest szczere. Wolę taki pomnik niż mdły, który wszyscy będą lubili. Wiem, że dla niektórych może być nawet obraźliwy. Ale spełnia swoją funkcję, bo przyciąga uwagę do dzielnicy. Wciąż stoi, a przecież mogli go spalić. W mroźne dni założyli mu nawet czapkę i podbity futrem kaptur. Klepią po ramieniu: „Cześć, Guma!”. Spotykają się przy nim, dyskutują. Niech ludzie mówią o tym, jak tu jest, że nie chcą tak żyć. Niech się tego nie wstydzą [Niech ludzie... 2009].

Wydaje się więc, że pomimo oporu pewnej grupy mieszkańców Pragi, twórczy wkład miejscowej młodzieży w rzeźbę legitymizuje i broni przed dewastacją. Z pewnością nie jest też bez znaczenia solidarnościowy i tożsamościowy aspekt „praskości”, który nakazuje szacunek dla „swoich”, więc także dla upamiętnionego pomnikiem Gumy. Definicja animatorów, w świetle której pomnik przyciąga uwagę do dzielnicy i nagłaśnia jej problemy, nie jest jednak podzielana przez mieszkańców. Dla tych ostatnich, pomnik jest raczej symbolem zbiorowej tożsamości, skonstruowanej m.in. na podstawie kategorii wspólnego trudnego doświadczenia życiowego, ale też swoistej dumy ze zdolności tej zbiorowości i jej indywidualnych przedstawicieli do przetrwania, dla której Guma stanowi kontrprzykład.

Jak pokazuje przypadek rzeźby Pana Gumy, brak społecznej, oddolnej legitymizacji pracy artysty na rzecz społeczności przez tą społeczność, może wywołać skutek uboczny w postaci przeniesienia punktu ciężkości w towarzyszącej publicznej (także medialnej) dyskusji na kwestie związane ze statusem

16 Komentarze pochodzą z forum internetowego warszawskiego wydania „Gazety Wyborczej”. Zob. wypowiedzi pod artykułem [Kowalska 2009]. 
sztuki i artysty w społeczeństwie, takie jak: Czy to jest sztuka? Do czego artysta ma prawo? Kogo reprezentuje? Kto za to płaci? Czy taka sztuka jest potrzebna? Czy ulica jest właściwym miejscem dla sztuki? Czy „ulica” rozumie sztukę? Jednocześnie dyskusja ta oddala się od kwestii rzeczywiście ważnych dla danej społeczności, które miały uzasadniać obecność artysty i nadawać sens jego działaniom. Przykładowo, zamiast pisać o sytuacji dzieci i młodzieży na Pradze Północ, lokalne gazety zajęły się „skandalem” wokół pomnika Pana Gumy, a fora internetowe zaroiły się od wypowiedzi negujących celowość stawiania pomnika „menelowi”. Nikt nie zapytał o zdanie młodych współtwórców rzeźby. Nikt nie zainteresował się tym, jaki wpływ miał na nich udział w projekcie. Nikt nie wymieniał ich $\mathrm{z}$ imienia i nazwiska jako równoprawnych autorów rzeźby ${ }^{17}$. Wykonanie i odsłonięcie pomnika wyznaczyło w tym przypadku granice publicznego działania poprzez sztukę. Co więcej, w połowie 2011 roku został on usunięty ze Stalowej ze względu na zły stan techniczny i do tej pory tam nie powrócił. Zamiast tego, Pana Gumę prezentowano w Pałacu Prezydenckim na wystawie Jaka sztuka dziś, taka Polska jutro (26.01. - 21.04.2013), a aktualnie rzeźba stanowi część ekspozycji $W$ sercu kraju w Muzeum Sztuki Nowoczesnej $(14.02 .2013-06.01 .2014)$

\section{Przykład 3: Import/Export, czyli inkluzja społeczna w mikroskali ${ }^{18}$}

Import/Export (2013-2014) w reżyserii Michała Stankiewicza to dokumentalny spektakl teatralny, a jednocześnie projekt, który można zaliczyć do stworzonej przez Granta H. Kestera [2004] kategorii sztuki konwersacyjnej, dialogicznej (conversational art, dialogical art). Ta podwójna klasyfikacja wiele mówi o jego charakterze (co w przypadku muralu czy rzeźby nie jest oczywiste). Teatr dokumentalny jest szczególną dziedziną teatru, w którym aktorami są zwykli ludzie, a treścią przedstawień (spektakli czy performansów) historie ich życia, ich prywatne doświadczenia przełożone na język sztuki. Sztuka dialogiczna polega zaś na stwarzaniu otwartych sytuacji komunikacyjnych pomiędzy różnymi (różniącymi się kulturowo, zajmującymi różne pozycje w strukturze społecznej, skonfliktowanymi) społecznościami lub grupami, w których ich członkowie mają szansę

17 Muzeum Sztuki Nowoczesnej, w której kolekcji znajduje się rzeźba Pana Gumy, przedstawia ją jako dzieło Pawła Althamera, stworzone „we współpracy z dziećmi i opiekunami z Grupy Pedagogiki i Animacji Społecznej Praga Północ". Zob. http://artmuseum.pl/pl/kolekcja/praca/althamer-pawel-guma [dostęp 10.08.2013].

18 Zob.: www.widok.org.pl [8.08.2013] oraz [Krutul 2013; Medek 2013; Młodzi Czeczeni... 2013]. 
przekroczyć społeczne podziały, identyfikacje i stereotypy na co dzień naznaczające ich wzajemne relacje, by później niejako przenieść to doświadczenie na zewnątrz. Do kategorii tej Kester zalicza różnorodne projekty interaktywne, procesualne, performatywne, oparte na dialogu, współpracy i autorefleksyjności, zorientowane na wytwarzanie kontekstu sprzyjającego komunikacji, a jednocześnie zmierzające do rozwiązania konkretnych (pozaartystycznych) problemów. Narzędziem sztuki dialogicznej jest według Kestera empatyczne poznanie (emphatic insight), które dokonuje się na trzech płaszczyznach:

1) relacji między artystą i uczestnikami,

2) relacji między uczestnikami,

3) relacji między uczestnikami i szerszą publicznością.

Pierwsza ma charakter asymetryczny: artysta zawsze występuje z pozycji outsidera i kulturowej władzy. Zmiana społeczna zachodzi przede wszystkim na drugiej i trzeciej. Sztuka dialogiczna może wytworzyć więzi między uczestnikami, a także „podważyć dominujące sposoby reprezentacji społeczności lub grupy i wytworzyć postawy głębszego zrozumienia i empatii względem tej społeczności/grupy wśród szerszej publiczności” [Kester 2004: 115, cyt. tłum. KN].

Spektakl Import/Export, zrealizowany przez Stowarzyszenie Edukacji Kulturalnej WIDOK w ramach większego projektu "Mieszkam w Białymstoku”, dobrze ilustruje opisane przez Kestera funkcje sztuki. Wytworzył bowiem społeczną przestrzeń, w której jego uczestnicy - młodzież czeczeńska i polska mogli komunikować się zarówno ze sobą nawzajem, jak i z szerszą publicznością (tą oglądającą spektakl na żywo i tą, która dowiedziała się o nim z mediów). W spektaklu występują nastoletni uchodźcy z Czeczenii, którzy od kilku lat mieszkają w Białymstoku, zarówno chłopcy, jak i dziewczęta, oraz ich polskie koleżanki ${ }^{19}$. Wpisując się $\mathrm{w}$ model Kestera, praca nad spektaklem stworzyła warunki międzykulturowego spotkania na trzech poziomach: między polskimi realizatorami (reżyserem, dźwiękowcem, widżejem, scenografką) a czeczeńskimi uczestnikami (aktorami), między uczestnikami czeczeńskimi i polskimi oraz między czeczeńskimi aktorami a w większości polską publicznością. Próbą tych relacji było otwarte dla publiczności spotkanie, nazwane teaserem spektaklu, utrzymane w konwencji reportażu, rozmowy reżysera z aktorami. Konwencja quasi-intymnego spotkania między ludźmi różnych narodowości i kultur z pewnością sprzyja przełamywaniu wzajemnych uprzedzeń i przezwyciężaniu zastanych podziałów społeczno-kulturowych. Dla nastoletnich Czeczenów motywacją do udziału w przedsięwzięciu była jednak przede wszystkim chęć

19 W spektaklu biorą udział: Zaurbek Vazaev, Zelichman Edilov, Bersan Mezhidov, Lorsan Mezhidov, Laura Mezhidov, Isa Ahmadov, Dżaneta Ahmadova, Oxana Ahmadova, Khava Ozdamirova, Khavashi Kosumova oraz Patrycja Kownacka, Natalia Siereda, Ida Matysek i Martyna Płońska. 
zrekonstruowania swojej własnej historii (uciekając z Czeczenii mieli po kilka lat, niewiele pamiętają, ich wspomnienia są porozrywane, fragmentaryczne) i opowiedzenia tej historii innym, Polakom. Dzięki projektowi dostrzegli w teatrze możliwość komunikacji z otoczeniem, które - jak się okazało - chce ich słuchać [Młodzi Czeczeni... 2013]. Udział w projekcie wzmacnia więc ich czeczeńską (a może czeczeńsko-polską) tożsamość.

Opowieści, które snują bohaterowie spektaklu są bardzo autentyczne i bezpośrednie, po części improwizowane, co potęguje w widzu poczucie kontaktu z prawdziwym człowiekiem (a nie wykreowaną postacią). Aktorzy właściwie nie grają, są sobą. Czasami trudno jest im mówić po polsku, czasami łamie im się głos, czasami przez narrację przebija stres i onieśmielenie obecnością publiczności. Czeczeni opowiadają o dzieciństwie w ojczyźnie, o rodzinnych stronach, ulubionych zabawach, zapamiętanych detalach, wojnie, przemocy, ucieczce, przetrzymywaniu na granicy, życiu w ośrodku, polskiej szkole, spotkaniach z Polakami, poznawaniu innej kultury, swojej tęsknocie za Czeczenią, ale też przywiązaniu do Polski. Mówią po polsku, mówią o serdeczności Polaków, o tym, że w Polsce czują się bezpiecznie i o tym, że większość ich znajomych to Polacy. Z perspektywy polskich uczestników projektu ich relacje z Czeczenami naznaczone są ambiwalencją: $\mathrm{w}$ opowiadanych historiach przyjaźni ciekawość innej kultury i radość z jej poznawania stopniowo zastępuje żal za utraconymi przyjaciółmi, którzy wyjechali dalej na Zachód. Spektakl porusza temat tymczasowości w relacjach międzykulturowych, nieobecny w dominującym dyskursie integracyjnym. To ta tymczasowość czyni z czeczeńskich uchodźców „modelowych" Obcych, o jakich pisał socjolog Georg Simmel [2006: 204]:

Jeśli wędrowanie jako brak związku z wszelkim konkretnym punktem przestrzeni jest pojęciowo przeciwieństwem trwałego przywiązania do danego, konkretnego punktu, to socjologiczna forma „obcości” stanowi w pewnej mierze syntezę obydwóch tych określeń. Zjawisko to ujawnia, że stosunek do przestrzeni jest, z jednej strony warunkiem, z drugiej zaś - symbolem stosunku do człowieka. Nie mamy tu na myśli „cudzoziemca” jako wędrowca, który dziś przychodzi, jutro odchodzi, ale osobę, która dziś przychodzi, jutro zaś zostaje - niejako potencjalnego wędrowca, który, aczkolwiek nie wyruszył dalej, nie zrezygnował też całkowicie z owej swobody przychodzenia i odchodzenia.

Obcy nie tylko uznają i realizują odmienne wartości kulturowe, ale także w każdej chwili mogą odejść. Stąd tytuł spektaklu Import/Export, który w wersji roboczej brzmiał Nie bierz tego do swojego serca. Spektakl dokonuje redefinicji strachu związanego z obecnością Obcych: strach przed obcością (rozumianą jako kulturowa odmienność) wypiera strach przed utratą Obcego. Otwartość 
na kontakt międzykulturowy, która jest głównym postulatem edukacji w tym zakresie, nie likwiduje napięcia między bliskością a dystansem w odniesieniu do Obcych. Coraz częściej musi mierzyć się z wyzwaniem przestrzenno-społecznej mobilności, która - w skali makro - stanowi barierę wzajemnej, międzykulturowej integracji.

Spektakl Import/Export powstał w szczególnym kontekście społecznym i politycznym, na który złożyły się: powtarzające się akty agresji wobec obcokrajowców (podpalanie mieszkań, pobicia, wyzwiska), ich szerokie medialne nagłośnienie (także w mediach ogólnopolskich), z jednej strony odgórne przyzwolenie na mowę nienawiści w dyskursie publicznym (uznanie przez prokuratora Dawida Roszkowskiego namalowanej na murze swastyki za symbol szczęścia, orzeczenie sędzi Aliny Krejzy-Aleksiejuk uznające za nieobraźliwe nazwanie Czeczenów „pasożytniczym ścierwem”), z drugiej - ostra retoryka sprzeciwu wobec nietolerancji na szczeblu centralnym („Idziemy po was”20), oraz doraźne działania różnych środowisk lokalnych: samorządu (koncert Białystok dla tolerancji), mediów (akcja Wykopmy rasizm z Białegostoku), środowisk twórczych i opiniotwórczych (akcja Zamaluj zło, facebookowa społeczność Normalny Białystok, antyrasistowski mural na budynku na osiedlu Leśna Dolina ${ }^{21}$ ). Uciekając się do metafory, możemy mówić o dwóch spektaklach: tłem spektaklu teatralnego jest spektakl społeczno-polityczny - w którym migranci, cudzoziemcy, Obcy zostali obsadzeni w roli niemej ofiary. Spektakl Import/Export odwraca tę logikę: ci, o których się mówi, pisze i dyskutuje zaczynają mówić o sobie, więcej - stają się partnerami w rozmowie. Stwarza sytuację, w której widzowie mogą usłyszeć, co młodzi Czeczeni mieszkający w Białymstoku mają im do (o)powiedzenia. W mikroświecie spektaklu prawo do wypowiedzi i bycia wysłuchanym zyskują ci, którzy są go pozbawieni na zewnątrz artystycznego kontekstu.

\section{Podsumowanie}

Każdy z trzech omówionych projektów można potraktować jako - mniej lub bardziej skuteczną - taktykę uzurpacji dostępu społecznej mniejszości do

20 Cytat $\mathrm{z}$ wypowiedzi ministra spraw wewnętrznych Mikołaja Sienkiewicza, skierowanej do skinheadów podczas jego wizyty w Białymstoku.

21 Mural przedstawia ciemnoskórą kobietę, która zdejmuje białą maskę. Podpisany jest słowami Kazimierza Przerwy-Tetmajera: „Ludzie są równi, tylko nierówność ich dzieli”. Wykonała go dwójka włoskich twórców streeartowych przy wsparciu grupy inicjatorów profilu Normalny Białystok i Spółdzielni Mieszkaniowej Słoneczny Stok, do której należy ściana. Jest to pierwszy społecznie zaangażowany mural w Białymstoku. 
sfery publicznej. W tym aspekcie tworzą one swego rodzaju kontinuum: od artystycznej kolonizacji przestrzeni, przez partycypację w tworzeniu sztuki, po upodmiotowienie w sferze publicznej. Przyjęcie perspektywy socjologicznej jako podstawy ich opisu i analizy, jako działań społeczno-artystycznych zorientowanych na inkluzję społeczną, pozwala ocenić ich skuteczność, rozumianą jako zdolność generowania zmiany społecznej, w sposób realistyczny, a nie życzeniowy.

Projekt „Universal” razi „kolonizatorskim” podejściem: brakiem humanistycznej wrażliwości (która nakazuje patrzeć na daną rzeczywistość społeczną oczami jej uczestników), uprzedmiotowieniem ubóstwa, wykorzystaniem społeczności dla własnych celów artystycznych. Odpowiadając na krytykę, Drozd tłumaczył, że „uprzedmiotowienie jeszcze bardziej podkreśla dramat tych ludzi” [Debiliada... 2010: 128]. Z socjologicznego punktu widzenia, problematyczność projektu „Universal” polega na tym, że chcąc zakwestionować reguły społecznej ekskluzji decydujące o niekorzystnym położeniu mieszkańców Dudziarskiej (poprzez wzmocnienie ich zbiorowej świadomości i poruszenie opinii publicznej), artyści je wzmocnili, utrwalili. Bez choćby minimalnego zintegrowania lokalnej społeczności wokół celów działania (włączenia jej członków w proces twórczy, uzgodnienia znaczeń, oddania im głosu) nie da się wywołać zmiany tych reguł. Można tylko pokazać, że takie - niesprawiedliwe - reguły istnieją (używając słów Drozda „podkreślić dramat tych ludzi”).

Rzeźba Pana Gumy powstała w sposób partycypacyjny, kolektywny i odwracający logikę wykluczenia. Partycypacyjne projekty artystyczne często ograniczają się do prostego wykonywania wizji artysty przez uczestników nie-artystów. Andre Breton nazwał kiedyś ten rodzaj sytuacji partycypacyjnych „sztucznymi piekłami” [za: Bishop 2012a: 6-7]. Poprzez prosty gest przeniesienia decyzyjności na uczestników, Althamer spowodował odwrócenie ról. To on stał się współwykonawcą artystycznej wizji chłopców z Pragi; ci jednak pozostali anonimowi. Uczestnikiem publicznej dyskusji (wprawdzie nie-ludzkim) stał się Pan Guma, a nie oni sami. To za pośrednictwem rzeźby, umieszczonej w przestrzeni publicznej, miała zawiązać się komunikacja między twórcami a odbiorcami: członkami społeczności i zewnętrznymi obserwatorami. Wraz z usunięciem Pana Gumy z Pragi w wymiarze społecznym rzeźba stała się całkowicie bezskuteczna.

Spektakl Import/Export zamienił w artystów uczestników projektu, przede wszystkim młodych uchodźców z Czeczeni. W ramach stworzonych przez projekt stali się oni aktorami - znanymi z imienia i nazwiska, i wynagradzanymi za swoją pracę (sic!). Rola reżysera, dźwiękowca, widżeja i innych profesjonalnych twórców zaangażowanych w projekt polegała na nadaniu artystycznej (estetycznej) formy prawdziwym i osobistym historiom, opowiedzianym przez 
uczestników, na stworzeniu warunków, w których mogli je przekazać szerszej publiczności. Centralnym momentem projektu była więc własna opowieść młodych Czeczenów i Czeczenek - autentyczna i w dużej mierze spontaniczna, opowiadana kolejnym widowniom, a nie mówiona z pamięci, opowiadana przy tym własnym głosem. Spektakl zaś przypominał spotkanie, rozmowę prowadzoną z kimś, kogo właśnie poznajemy. Dzięki temu miał znacznie większy potencjał komunikacyjny niż rzeźba Pana Gumy, odtwarzająca typowy sposób „pracy sztuki”, polegający na „zamknięciu” w obiekcie artystycznym pewnej treści przez jego twórcę/twórców, którą odbiorcy mają z niego z kolei „wydobyć”.

Spośród trzech omówionych projektów tylko Import/Export stworzył warunki, w których uczestnicy mogli rzeczywiście komunikować się z szerszą publicznością, sami opowiadając o sobie, swoich doświadczeniach i emocjach. Roman Pawłowski widzi w tym siłę teatru dokumentalnego, który „sięga głębiej, pokazuje problemy z perspektywy jednostki [...], dzięki czemu pomaga nam lepiej rozumieć świat” [Pawłowski... 2010]. W projekcie „Universal” społeczność Dudziarskiej została całkowicie pozbawiona głosu, podwójnie wykluczona. Pan Guma miał z kolei reprezentować problemy mieszkańców Pragi, a więc niejako mówić $\mathrm{w}$ ich imieniu czy też za nich (choć sam Althamer, co należy podkreślić, nie rościł sobie prawa do reprezentowania społeczności). Kontrowersje wywołane przez dwa ostatnie projekty straciły zdolność generowania zmiany społecznej percepcji wykluczenia (przestrzennego i ekonomicznego) wraz z przeniesieniem uwagi opinii publicznej ze społecznego problemu na kwestie związane ze sztuką i rolą artystów. Wydaje się więc, że Import/Export ma wśród omówionych działań największy potencjał naruszania - choć tylko w mikroskali - dominujących reguł społecznej ekskluzji i inkluzji. W tym przypadku problemem pozostaje jednak niewielka liczba granych spektakli, a w konsekwencji także odbiorców, uczestników teatralnego spotkania ${ }^{22}$.

Namalowanie muralu zwracającego uwagę na jakiś społeczny problem, czy uobecniającego jakąś wykluczoną zbiorowość w przestrzeni publicznej, jest działaniem typowo artykulacyjnym czy manifestacyjnym. Samo podjęcie aktywności twórczej przez osobę wykluczoną także nie jest wystarczającym środkiem przełamania jej wykluczenia (choć może mieć sens terapeutyczny). Równie ważny jest rodzaj i kontekst tej aktywności: podmiotowe, sprawcze uczestnictwo, kolektywne działanie, otwartość procesu twórczego, wyjście w przestrzeń publiczną, zorientowanie na zmianę społeczną. Procesy społecznej ekskluzji i inkluzji jako obszar artystycznej interwencji i współpracy z nie-artystami stawiają twórców

22 W 2014 roku spektakl Import/Export, pokazany dotąd zaledwie siedem razy, został zakwalifikowany do programu Teatr Polska, co pozwoli na zwiększenie liczby jego odbiorców i dotarcie do bardziej zróżnicowanej publiczności. 
wobec konieczności zmiany repertuaru działania w sposób eliminujący bariery uczestnictwa, rezygnacji przez artystę z pełnej kontroli nad dziełem/działaniem i podjęcia wysiłku zbiorowego konstruowania jego znaczenia.

Przyglądając się omówionym projektom, można wyciągnąć kilka ważnych wniosków dotyczących wykorzystania sztuki jako narzędzia społecznej inkluzji. Po pierwsze, sama ekspozycja na sztukę nie spełnia tej funkcji; przeciwnie, wzmacnia poczucie wykluczenia i alienacji, szczególnie jeśli jest to sztuka niezrozumiała dla odbiorcy. Po drugie, działanie na rzecz inkluzji społecznej poprzez sztukę wymaga pogłębionego rozpoznania kontekstu społecznego w jego różnych wymiarach: ekonomicznym, kulturowym, historycznym. Najlepiej jeśli identyfikacja potrzeb i problemów danej grupy czy społeczności odbywa się przy jej udziale - jej członkowie są przecież najlepszymi ekspertami w kwestii własnego życia. Po trzecie, sztuka służąca społecznej inkluzji musi być partycypacyjna, a partycypacja nie powinna ograniczać się do społeczności czy grup wykluczonych, a raczej stwarzać sytuacje komunikacji, dialogu ponad zastanymi podziałami. Uczestnictwo powinno mieć charakter zbiorowy, kolektywny, kooperatywny. Nie może też sprowadzać się do wykonawstwa (realizacji z góry narzuconej wizji artysty), musi być podmiotowe i twórcze. I w końcu, warunkiem inkluzji jest upublicznienie efektu działania. Przez zaprezentowanie tego efektu w miejscu publicznym, medialne relacje, dyskusję zainicjowaną w środowisku lokalnym sztuka może wpływać na społeczne wyobrażenia, a nawet działania polityczne. Pod warunkiem jednak, że zbiorowo tworzona narracja nie zostanie przekierowana przez media w stronę „skandalu”. Stąd szczególne znaczenie współpracy artystów z dziennikarzami jako kontrolerami sfery publicznej. Można więc zaryzykować stwierdzenie, że sztuka jest tym skuteczniejsza jako narzędzie społecznej inkluzji, im mniej jest sztuką. Im bardziej oddala się od mechanizmów świata sztuki. Im bardziej zbliża do życia społecznego, lecz nie na zasadzie zasysania go, zamieniania w temat przedstawienia, ale wyposażania jego uczestników w nowe, niekonwencjonalne narzędzia kolektywnego działania w sferze publicznej. Im bardziej jest sztuką społeczną.

\section{Bibliografia}

Bishop C. (2012a), Artificial Hells. Participatory Art and the Politics of Spectatorship, Londyn Nowy Jork

Bourriaud N. (2010), Estetyka relacyjna, Kraków

Clover D.E., Stalker J. (red.), (2007), The Arts and Social Justice. Re-crafting Adult Education and Community Cultural Leadership, Leicester 
Debiliada. Wytwór ideologii (2010), rozmowa A. Hudzika z G. Drozdem, „Notes na 6 Tygodni”, nr 65: 126-133

Domański H. (2004), Struktura społeczna, Warszawa

Graves J.B. (2005), Cultural Democracy. The Arts, Community, and the Public Purpose, Urbana - Chicago

Kabakow I. (2010), Projekt publiczny albo duch miejsca, [w:] E. Rewers (red.), Miasto w sztuce - sztuka miasta, Kraków: 342-354

Kester G.H. (2004), Conversation Pieces. Community and Communication in Modern Art, Berkeley - Los Angeles - Londyn

Kowalska M. (2010), Demokracja jako dekonstrukcja struktur społecznych, [w:] P. Gliński, I. Sadowski, A. Zawistowska (red.), Kulturowe aspekty struktury społecznej. Fundamenty, konstrukcje, fasady, Warszawa: 104-116.

Kwon M. (2004), One Place After Another: Site-Specific Art and Locational Identity, Cambridge - Londyn

Lacy S. (1989), Fractured Space, [w:] A. Raven (red.), Art in the Public Interest, Ann Arbor Londyn: 287-301.

Lacy S. (red.), (1995), Mapping the Terrain: New Genre Public Art, Seattle - Waszyngton

Lippard L.R. (1984), Community and Outreach: Art Outdoors, In the Public Domain, [w:] tejże, Get the Message? A Decade of Art for Social Change, Nowy Jork

Marshall G. (red.), (1998), Dictionary of Sociology, Oxford

Niziołek K. (2008), Sztuka i aktywność obywatelska, [w:] A. Kościański, W. Misztal (red.), Społeczeństwo obywatelskie. Między idea a praktyka, Warszawa: 235-265

Niziołek K. (2009a), Publiczna, zaangażowana, społecznościowa? O sztuce jako formie aktywności obywatelskiej, „Trzeci Sektor”, nr 19: 28-37

Niziołek K. (2009b), Sztuka jako enklawa aktywności obywatelskiej, [w:] L. Gołdyka, I. Machaj (red.), Enklawy życia społecznego. Kontynuacje, Szczecin: 209-225

Niziołek K. (2011), Edukacja międzykulturowa poprzez sztukę, „Pogranicze. Studia społeczne” t. 17, cz. 1: 149-163

Niziołek K. (2012), Pomnik, instalacja, działanie... Trajektorie sztuki publicznej w posttransformacyjnej Polsce, „Dekada Literacka” nr 2/3: 31-41

Niżyńska A. (2011), Street art jako alternatywna forma debaty publicznej w przestrzeni miejskiej, Warszawa

Parkin F. (1979), Marxism and Class Theory: A Bourgeois Critique, Londyn

Piotrowski P. (2010), Agorafilia. Sztuka i demokracja w postkomunistycznej Europie, Poznań

Potocka M.A. (2008), Prywatna studnia - publiczny umyst, [w:] tejże, To tylko sztuka, Warszawa: $246-255$

Raven A. (red.), (1989), Art in the Public Interest, Ann Arbor - Londyn

Simmel G. (2006), Obcy, w: tegoż, Most i drzwi. Wybór esejów, Warszawa: 204-212

Weber M. (1978), Economy and Society. An Outline of Interpretative Sociology, Berkeley - Los Angeles - Londyn

Webster M. (red.), (1997), Community Arts Workers: Finding Voices, Making Choices, Bramcote Hills

Wnuk-Lipiński E. (2005), Socjologia życia publicznego, Warszawa 


\section{Źródła internetowe}

Bishop C. (2012b), In the Age of the Cultural Olympiad, We're All Public Performers, „The Guardian” 23.07.2012, http://www.theguardian.com/commentisfree/2012/jul/23/cultural-olympiad-public-performers/print [11.08.2013]

Drozd G. (2010), Strzeż się tych miejsc, „Obieg” 27.11.2010, http://www.obieg.pl/fokus/19552 [7.08.2013]

Kowalska A. (2009), Pan Guma, czyli prawdziwy pomnik warszawski, „Gazeta Wyborcza - Warszawa” 13.12.2009, http://warszawa.gazeta.pl/warszawa/1,95158,7360156,Pan_ Guma_czyli_prawdziwy_pomnik_warszawski.html [10.08.2013]

Krutul U. (2013), To był wyrazisty i udany „Import/Export”, „Gazeta Współczesna” 02.07.2013, http://www.e-teatr.pl/pl/artykuly/165512.html [08.08.2013]

Lisicki G. (2009), Guma znów stoi na stalowej. Promocja menela czy sztuka?, „Gazeta Wyborcza - Warszawa” 16.12.2009, http://warszawa.gazeta.pl/warszawa/1,34889,7373583,Guma_ znow_stoi_na_Stalowej_Promocja_menela_czy_sztuka_html [10.08.2013]

Medek K. (2013), Odnaleziony smak pigwy. Spektakl o białostockich Czeczenach, „Gazeta Wyborcza - Białystok", 30.06.2013, http://bialystok.gazeta.pl/bialystok/1,35241,14197322,Odnal eziony_smak_pigwy_Spektakl_o_bialostockich_Czeczenach.html [08.08.2013]

Młodzi Czeczeni w Białostockim Teatrze Lalek (2013), rozmowa A. Bajguza z D. Ahmadovą, I. Ahmadovem, B. Mezhidovem i M. Stankiewiczem, 28.05.2013, http://www.radio.bialystok.pl/kultura/wydarzenia/id/99429 [8.08.2013]

Niech ludzieniewstydzą sięPragi (2009), rozmowa A. Kowalskiej z A. Orłowskim, „Gazeta Wyborcza - Warszawa” 26.12.2009, http://warszawa.gazeta.pl/warszawa/1,34889,7397190, Niech_ludzie_nie_wstydza_sie_Pragi_html [10.08.2009]

Pawłowski: Teatr dokumentalny - psychoterapia dla małych miasteczek (2010), rozmowa P. Walaszkowskiego z R. Pawłowskim, „Krytyka Polityczna” 14.12.2010, http://www.krytykapolityczna.pl/Wywiady/PawlowskiTeatrdokumentalny-psychoterapiadlamalychmiasteczek/menuid-77.html [10.08.2013]

Rypson P. (2010), Kwadrat na Dudziarskiej, „Obieg” 27.11.2010, http://www.obieg.pl/ fokus/19555 [07.08.2013]

Sikora P. (2010), Rudoweglowiec „Ibupron”, „Obieg” 27.11.2010, http://www.obieg.pl/ fokus/19563 [07.08.2013]

Szabłowski S. (2011), Utopia do kwadratu, „Zwierciadło” 15.04.2011, http://zwierciadlo. $\mathrm{pl} / 2011 / \mathrm{kultura} /$ sztuka/utopia-do-kwadratu [07.08.2013]

Watts P. (2010), Grzegorz Drozd: Animowanie wykluczonych w przestrzeni publicznej, „Obieg” 27.11.2010 http://www.obieg.pl/fokus/19569 [07.08.2013]

Wokół kolekcji. Andrzej Orłowski i Tomek Szczepański opowiadaja o „Gumie” Pawła Althamera (2009), 14.01.2009, http://artmuseum.pl/pl/doc/video-wokol-kolekcji lub http://vimeo. com/2952580\# [10.08.2013] 


\section{SUMMARY}

\section{Art as a Means of Social Inclusion from Sociological Perspective}

The article is focused on the civic practices that fall into the category of social art. Applying sociological perspective, in particular closure theory (as introduced by Max Weber, and developed by Frank Parkin), and referring to the modern concept of cultural democracy, the authoress compares three artistic projects: Universal (led by Grzegorz Drozd), Guma (Paweł Althamer), and Import/Export (Michał Stankiewicz), in order to assess the capability of social art to transform the processes of social closure. The three projects not only differ in terms of artistic means (mural, sculpture, theatre), but also present varied strategies of "usurpation", that is of affecting the rules of social inclusion (incorporation) and exclusion (marginalisation): from disturbance of the society's symbolic order, through articulation of local collective identity, to intercultural (and, at the same time, interpersonal) encounter. The cases, which reveal both possibilities, and limits (or traps) of social art, have been selected so as to create points of critical reference for a more reflective and self-conscious social practice. Hence, at the end, the authoress provides a list of practical recommendations to be used by artists, activists and educators who are willing to resort to social art as a means of social inclusion.

Keywords:

closure theory, social art, social inclusion 